\title{
Comfort properties of nano-filament polyester fabrics: sensory evaluation
}

\author{
MUSADDAQ AZEEM
}

DOI: $10.35530 /$ IT.069.01.1440

AMAL BOUGHATTAS

\author{
HAFIZ FAISAL SIDDIQUE \\ ANTONIN HAVELKA \\ SAJID HUSSAIN
}

\section{REZUMAT - ABSTRACT}

\section{Proprietățile de confort ale țesăturilor din nano-filament de poliester: evaluare senzorială}

În acest articol, este prezentată o lucrare experimentală pentru evaluarea proprietăților senzoriale ale țesăturilor din nano-filament de poliester. În acest scop, o țesătură din nano-filament de poliester a fost realizată și comparată cu țesături din: amestec poliester/bumbac (PC) şi, respectiv, poliester/viscoză (PV), utilizând sistemul de evaluare Kawabata (sistemul KES), cu scopul de a evalua tușeul pe baza caracteristicilor mecanice. Rezultatele au arătat că țesăturile realizate în amestec PC și PV au fost mai rigide decât țesătura din nano-filament de poliester. O valoare mai mare a tușeului (THV) a dus la o rigiditate mai mică (Koshi), la o netezire (Numeri) și la un grad de umplere (Fukurami) mai mari. Valorile tușeului țesăturii din amestec PV au fost mai apropiate de cele ale țesăturii din nano-filament de poliester față de cele ale țesăturii PC. Rezultatele generale ale caracteristicilor de rezistență la tracțiune, forfecare, încovoiere, compresiune și de suprafață ale țesăturilor din nano-filament de poliester au fost mai bune în comparație cu cele ale țesăturilor în amestec PC și PV.

Cuvinte-cheie: confort senzorial, tușeul țesăturii, țesătură din nano-filament de poliester, țesătură în amestec PC și PV

\section{Comfort properties of nano-filament polyester fabrics: sensory evaluation}

In this article, an experimental work is presented to evaluate the sensorial properties of polyester fabric constructed by nano-filament yarn. For this purpose Nano Filament polyester fabric was fabricated and compared with the spun polyester/cotton (PC) and polyester/viscose (PV) blended fabric by using Kawabata evaluation system (KES-system) to assess the handle of the fabric based on mechanical characteristic. The results revealed that the fabric made from PC and PV blended fabric were stiffer than nano-filament polyester fabric. The higher hand value (THV) resulted in lower stiffness (Koshi), and higher smoothness (Numeri) and fullness (Fukurami). Hand values of PV blended fabric were close to nano-filament polyester fabric rather than PC fabric. The overall results of tensile, shearing, bending, compression and surface characteristics of nano-filament polyester fabric were found best as compared to PC and PV blended fabric.

Keywords: Sensorial comfort, Fabric handle, Nano-filament polyester fabric, PC and PV blended fabric

\section{INTRODUCTION}

Clothing comfort is divided into three categories like psychological, tactile and thermal comfort. Psychological comfort is usually concerned to the up to date fashion trend and acceptability in the society and also deals with the fabric properties. The tactile or sensorial comfort is interconnected with fabric surface and mechanical properties [1]. Sensorial evaluation plays a major role to identify the materials in addition for technical specification. All textiles material have different characteristic from each other with their technical structures like strength, performance flexible, elastic, easy to pleat and shape, comfortable in aesthetic and sensorial aspects. In order to find a procedure for the sensational evaluation of textiles, the term "fabric handle" is commonly used [2].

The fabric handle is defined as "total sensations being felt by human fingers during the fabric touching" [3]. This parameter is associated to the fabric properties, such as surface contour (roughness, smoothness), surface friction, resilience, flexibility, elasticity, compressibility, density and thermal character. Raw material, yarn and fabric structure as well as finishing treatment affect the THV (total hand value) [4-7].
Polyester fiber is one of widely consumed of all fibers (about 70\%). However, it is known by its hydrophobic (low moisture regain) and electrostatic nature. To obtain better moisture transport, researchers are thinking to modified polyester, especially with using multifilament and fine filament yarns [8-9].

Multifilament polyester yarns are made by aggregating many continuous filaments together. They are characterized by their high strength, good chemical properties, acceptable elasticity and its circular cross section. Moreover, the voids between these filaments form capillary channels and facilitate liquid flow. In knitted fabrics, using multifilament polyester yarns instead of monofilament can facilitate moisture transport and liquid absorption [10]. Fabric structure is also an important factor influences its mechanical properties. In knitting structure, the tightness factor affects the handle, stiffness increases with the increase of tightness of fabric which is related to bending rigidity. Fullness, softness and smoothness are inversely proportion to the tightness factor [11]. Nowadays we talk about ultra fine filaments or nanofilaments of polyester with diameters in the range of a few nanometers and lengths up to kilometers are used in different range of important technological 
applications such as functional fabrics, biomedicine, composite, etc. The nano-filaments of polyester are characterized by their high tenacity, large surface area per unit mass and small pore size [12]. Furthermore, they have high fibre interconnectivity and nano-scale inertial space compared to conventional multifilament of polyester. These properties will force the transfer of moisture away from the skin to the outside of the fabric because there is a good correlation between permeability and the inter-fibre and the intra-fibre voids of a tightly woven fabric [13]. THV is the measure of sensorial comfort designated with the use of Kawabata evaluation system (KES system) [3].

The use of multifilament yarn in fabric is also an important solution to replace cotton. In hard activity, when wearer get sweat suffers discomfort. To get rid of this problem multifilament polyester is a substitute material for him/her. Long capillaries provide better transportation and force the perspiration to be evaporated. Quick evaporation considers a main comfort character in warm weather. However, filament polyester fabric helps the drying of fabric in hot weather. The nano-filament fabric are very useful for the under garments especially gloves. Better water transport properties make it more useful for industrial point of view.

\section{MATERIALS AND METHODS}

\section{Material}

Nano-filament samples were got from a Japanese commercial factory to assess their comfort properties for next to skin fabric. Fabric SEM images are given in figure 1.

\begin{tabular}{|c|c|c|}
\hline Sample \# & $\begin{array}{c}\text { GSM } \\
\left(\mathrm{g} / \mathrm{m}^{2}\right)\end{array}$ & $\begin{array}{c}\text { Thickness } 1 \\
(\mathrm{~mm})\end{array}$ \\
\hline S1 & $200 \pm 2$ & 0.44 \\
\hline S2 & $250 \pm 2$ & 0.55 \\
\hline
\end{tabular}

Table 2

\begin{tabular}{|l|c|c|}
\hline Fineness & dtex & $152 \pm 10$ \\
\hline Tenacity & $\mathrm{N}$ & $4.5 \pm 0.3$ \\
\hline Elongation at break & $\%$ & $32 \pm 5$ \\
\hline Boil Shrinkage & $\%$ & $2 \pm 1$ \\
\hline
\end{tabular}

Both samples were made of the same yarn so the images presented the same filament diameter (table 1 and table 2).

\section{Methods}

The Kawabata evaluation system is used to measure the mechanical properties of fabrics [14]. The system was invented by a team under the supervision of Professor Kawabata in Kyoto University Japan. Kawabata evaluation system consists of four modules KES-FB1, KES-FB2, KES-FB3 and KES-FB4 for tensile/shearing, bending, compression and surface characteristic evaluation respectively.

KES-FB1 Tensile and Shear Tester; this module moves mechanically as shown in figure $3, a$. Data obtained from this system is helpful to determine stiffness and anti-drape stiffness. These characteristics are correlated with tendency for wrinkles and stability. KES-FB2 Pure Bending Tester; this module also performs mechanically as shown in figure $3, b$. Obtainable data includes bending rigidity and recoverability for

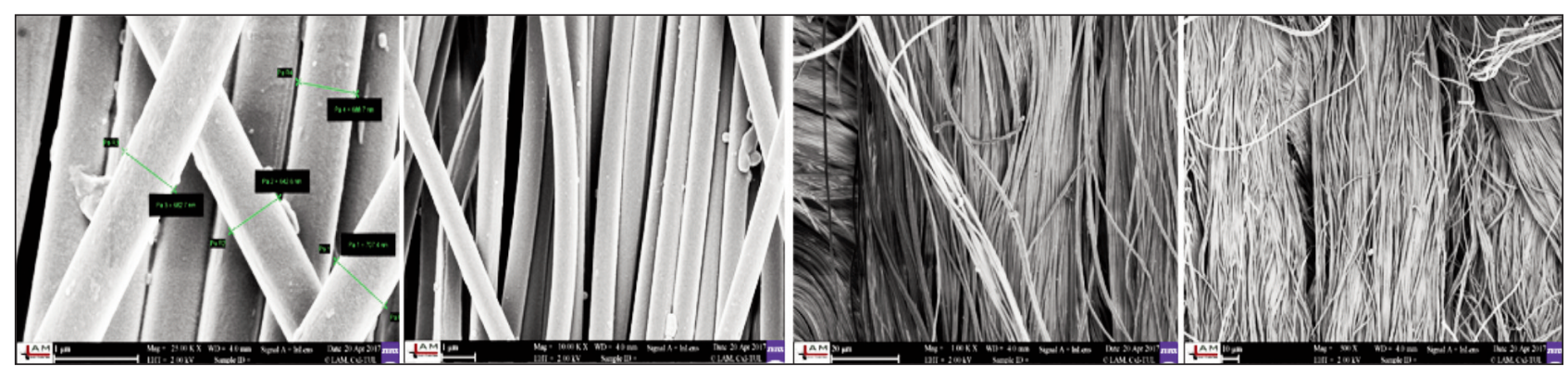

Fig. 1. SEM images of sample 1 with almost 680 nano-meter diameter

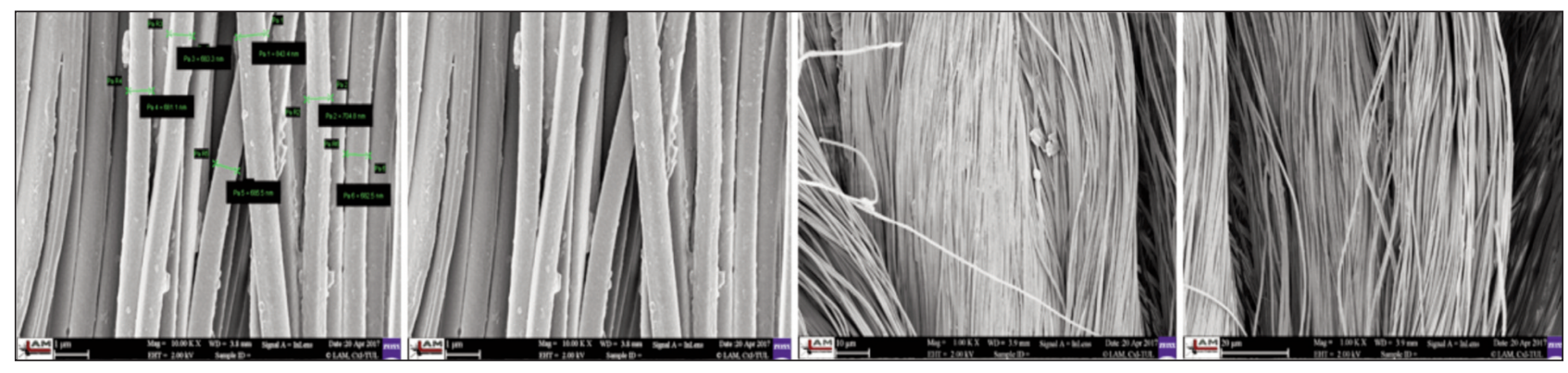

Fig. 2. SEM images of sample 2 with almost 670 nano-meter diameter 


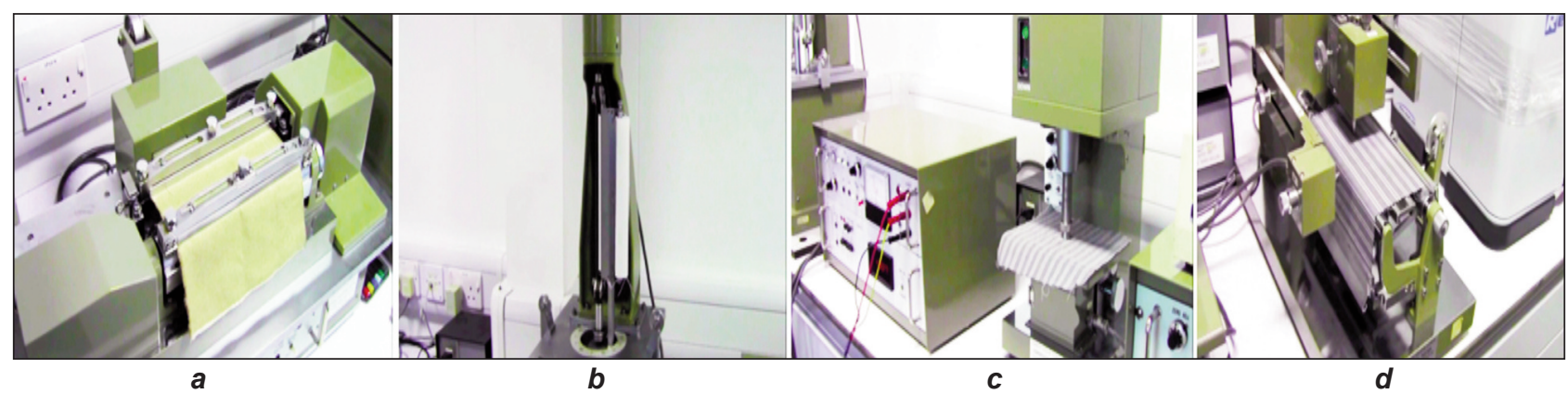

Fig. 3. Kawabata four modules KES-FB1, KES-FB2, KES-FB3 and KES-FB4

Table 3

\begin{tabular}{|l|l|l|}
\hline \multicolumn{2}{|c|}{ Hand } & \multicolumn{1}{c}{ Definition } \\
\cline { 1 - 2 } Joshi & \multicolumn{1}{|c|}{ English } & \\
\hline Numeri & Stiffness & $\begin{array}{l}\text { A feeling interconnected for the most part to the bending property. Springy } \\
\text { behavior stimulates this sensation of touching. The high density fabrics } \\
\text { constructed with elastic yarn generally own this property intensively. }\end{array}$ \\
\hline Fukurami & Fullness and softness & $\begin{array}{l}\text { Aggregation of flexible, soft and smooth feelings. Cashmere fabric exhibits } \\
\text { higher value of such feelings. }\end{array}$ \\
springy feature in fabric thickness and compression.
\end{tabular}

such targets as general fabric, cloth, paper, nonwoven fabric, and film. Bending numerical data is effective to assess the softness, stiffness and fullness, anti-drape stiffness.

KES-FB3 Compression Tester; this module behaves like pushing with a finger as seen in figure $3, c$. Compression numerical values are applicable to estimate the smoothness, fullness and softness, antidrape stiffness. KES-FB4 Surface Tester, this module responds to replicate the surface of human finger to fabric properties as shown in figure 3,d. Surface roughness and friction statistics are valuable to regulate crispness, softness and fullness, smoothness.

\section{Results and discussions}

Each property of the Kawabata evaluation system is elaborated for the sample 1 and sample 2. Polyester/ cotton (50:50) and Polyester/viscose (50:50) fabric were taken as reference for the comparison. Definitions of primary hand values are shown in table 3 [14].

\section{Tensile properties}

Table 4 portraying tensile characteristics (Extensibility, EM; linearity of load extension curve, LT; tensile energy, WT and tensile resilience, TR) of fabric samples. All mentioned tensile properties of fabric defined the level of clothing performance and utility comfort. Hand feel characteristic is basic parameter to assess the quality of fabric for common consumer so in our case the extensibility results are best than results measured in other studies [16].

Table 4 shows that Sample 02 exhibit higher (exceeds 88\%) EM value (mean=11.15) than sample 01, EM (mean=5.89). Load Elongation curve (LT) represents the extensibility of the fabric structure and Load-Elongation curve. Table 4 depicts that Sample 02 has less LT value than sample 01 which is inverse relation to extensibility trend and represents sample 02 is more comfort bale than sample 01. As mentioned by researcher that lower the LT value, higher the fabric elasticity results in higher clothing comfort [17]. Tensile energy (WT) defined as the area beneath load elongation curve [15]. Higher value of WT, represent higher fabric strength but adversely affect the hand feel. Table 4 shows that WT of sample 02 (mean=2.5) is almost 2.5 times higher than the sample 01 (9.27) that is due to greater a real density $\left(\mathrm{g} / \mathrm{m}^{2}\right)$. The same results are shown in figure 4 for

Table 4

\begin{tabular}{|l|c|c|c|c|c|c|}
\hline \multirow{2}{*}{ Parameter } & \multicolumn{3}{|c|}{ Sample 1 } & \multicolumn{3}{c|}{ Sample 2 } \\
\cline { 2 - 7 } & Wale & Coarse & Mean & Wale & Coarse & Mean \\
\hline EM [\%] & 7.59 & 4.20 & 5.89 & 14.43 & 7.87 & 11.15 \\
\hline LT [-] & 0.786 & 0.789 & 0.788 & 0.752 & 0.607 & 0.680 \\
\hline WT [g.cm/cm $\left.{ }^{2}\right]$ & 12.37 & 9.27 & 10.82 & 32.17 & 19.53 & 25.85 \\
\hline RT [\%] & 31.58 & 52.84 & 41.96 & 19.62 & 50.15 & 34.89 \\
\hline
\end{tabular}




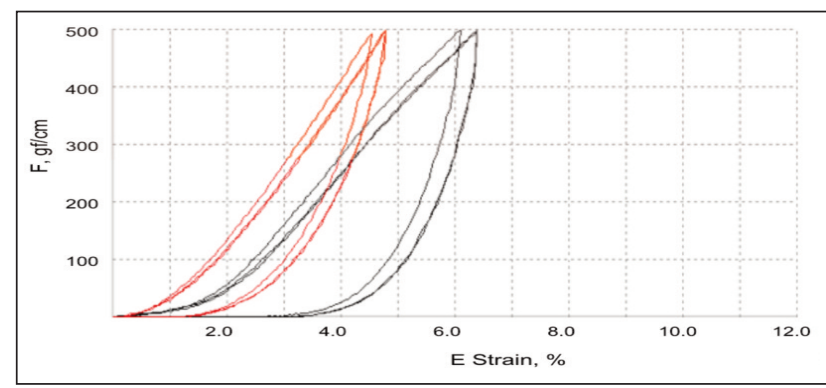

a

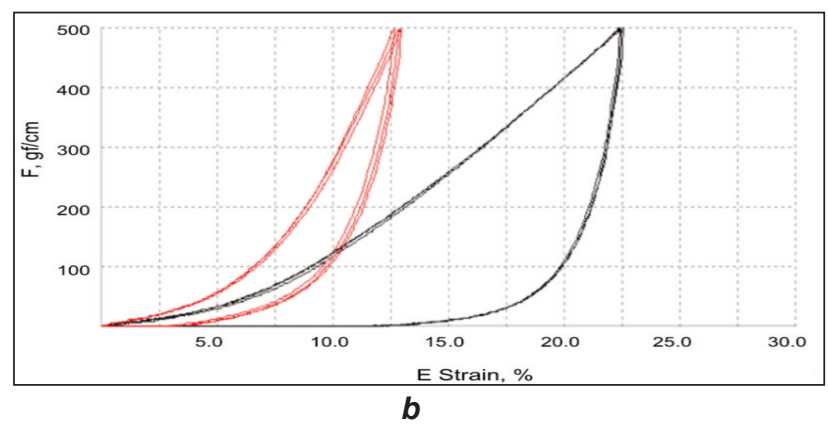

Fig. 4. The load-elongation hysteresis, red curve represents wales direction and black curve courses direction for sample $1(a)$ and sample $2(b)$ wales and courses of fabric. Both the samples (sample 01 and sample 02) tensile strains were compared with already done studies. Both these samples exhibit higher values of tensile strain (EM) and tensile energy (WT) are greater than polyester/viscose blended suiting fabric and polyester/cotton blended fabric, portray our samples are best in comfort properties [18-19]. Linearity of tensile (LT) property of nano-filament polyester fabric is almost same as of polyester/ viscose fabric and less than polyester/cotton fabric [18-19]. In case of tensile resilience (RT), the average values are lacking with better handle than $\mathrm{P} / \mathrm{V}$ and $\mathrm{P} / \mathrm{C}$ for both nano-filament fabrics [18-19].

\section{Shear properties}

Fabric shear property is described by shear rigidity (G) measured at $0.5^{\circ}$ and $5^{\circ}$ shear angle hysteresis of shear force as shown in table 5 .

Fabric samples are subjected to deform by an extensive range to assess their shear behavior. This method is of great importance used to quantify handling, pliability and drape-ability of fabrics, so shearing hysteresis explains the friction force between the cross-over point of wales and courses during the shrinkage or stretch. Concerning handling, less value of shearing is favorable [20-21]. Similarly, lower $2 \mathrm{HG}$ and 2 HG5 values for hysteresis are also preferred. However, shear hysteresis loop relates that the fabric deformation cannot be retrieve to its original shape. Table 5 and figure 5 show that sample 02 exhibit excellent shearing behavior than sample 01. Various studies exist in which different types of materials have been chosen to evaluate their mechanical interaction to skin. Only, shear properties of P/V with different possible blend ratio are found to be better than nano-filament fabrics [18]. Although, Sample 1 and Sample 2 exhibited good shearing rigidity and shearing force hysterics than P/C studied by Bartkowiak et al. [19].

Table 5

\begin{tabular}{|l|c|c|c|c|c|c|}
\hline \multirow{2}{*}{ Parameter } & \multicolumn{3}{|c|}{ Sample 1 } & \multicolumn{3}{c|}{ Sample 2 } \\
\cline { 2 - 7 } & Wale & Coarse & Mean & Wale & Coarse & Mean \\
\hline G [g/cm.deg] & 3.88 & 3.94 & 3.91 & 2.25 & 2.09 & 2.17 \\
\hline 2HG [g/cm] & 7.39 & 6.84 & 7.11 & 6.75 & 4.77 & 5.76 \\
\hline 2HG5 [g/cm] & 5.85 & 8.33 & 7.09 & 5.48 & 6.17 & 5.82 \\
\hline
\end{tabular}

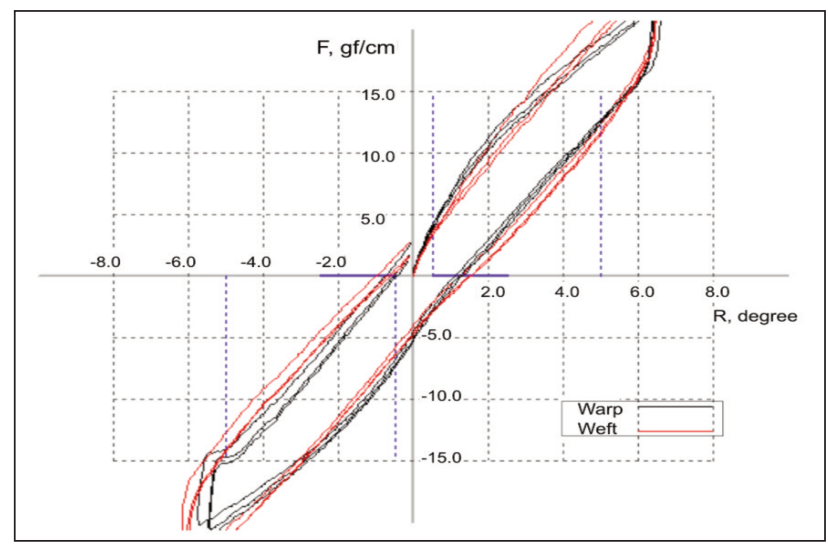

a

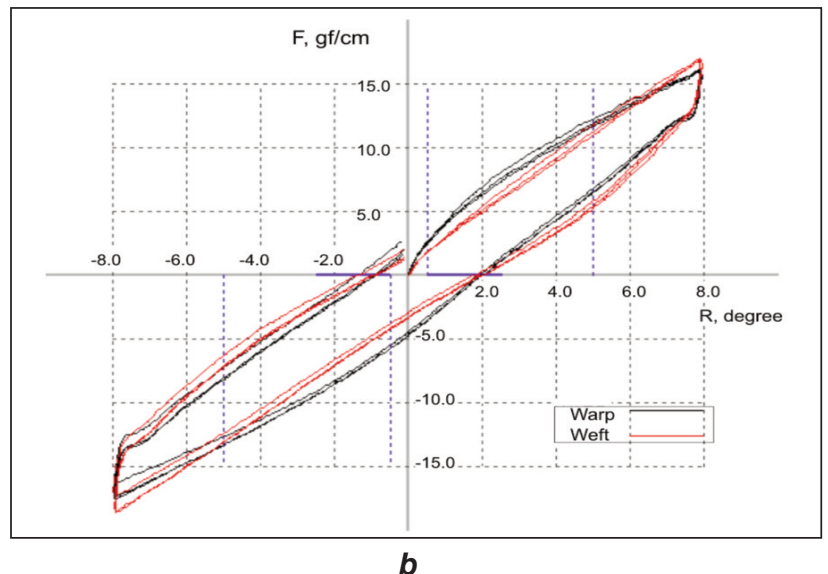

b

Fig. 5. The shear stress-strain hysteresis sample 1 and sample 2. Red curve represents wales direction and black curve courses direction 


\begin{tabular}{|l|c|c|c|c|c|c|}
\hline \multirow{2}{*}{ Parameter } & \multicolumn{3}{|c|}{ Sample 1 } & \multicolumn{3}{c|}{ Sample 2 } \\
\cline { 2 - 7 } & Wale & Coarse & Mean & Wale & Coarse & Mean \\
\hline B $\left[\mathrm{g} \cdot \mathrm{cm}^{2} / \mathrm{cm}\right]$ & 0.036 & 0.048 & 0.042 & 0.029 & 0.067 & 0.048 \\
\hline 2HG $[\mathrm{g} . \mathrm{cm} / \mathrm{cm}]$ & 0.0413 & 0.0412 & 0.0412 & 0.0401 & 0.0893 & 0.0647 \\
\hline
\end{tabular}

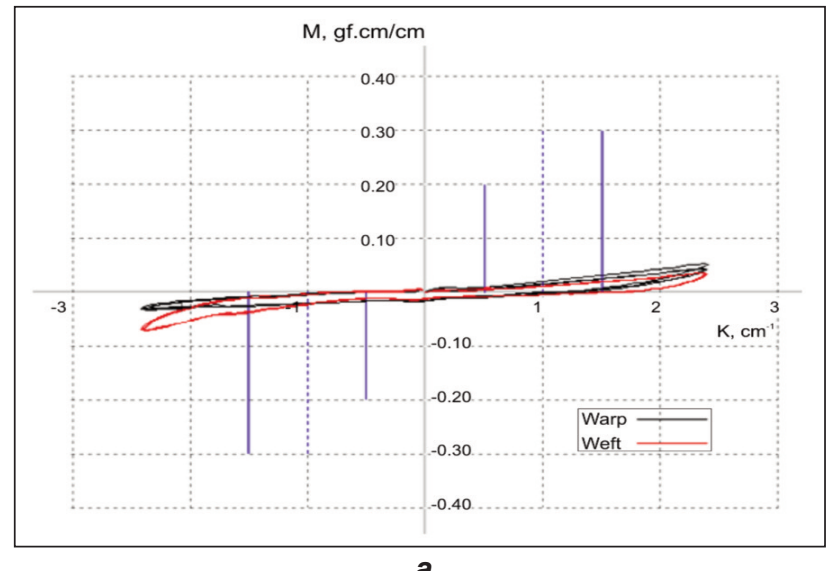

a

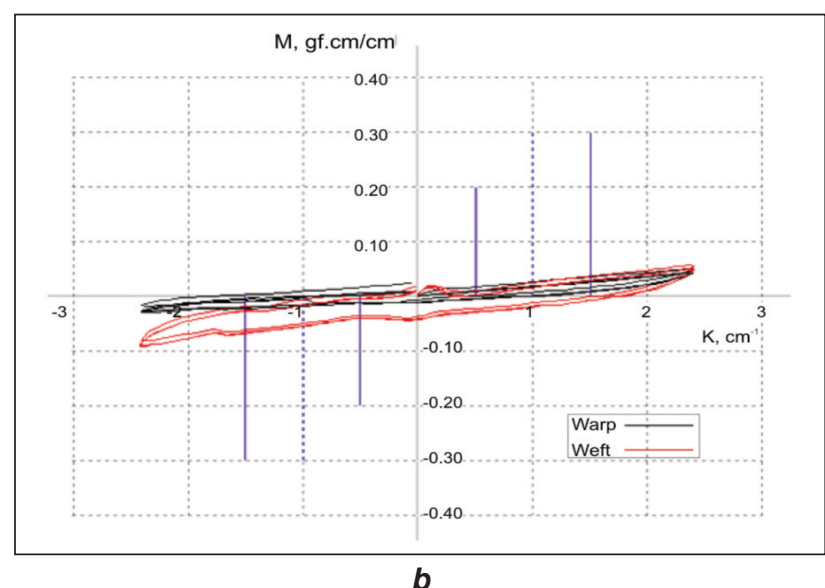

$b$

Fig. 6. The bending hysteresis for sample 1 and 2 in (a) and (b) respectively. Red curve represents wales direction and black curve courses direction

\section{Bending properties}

$B$ (bending rigidity) value defines that how smoothly the fabric is being bent. Bending rigidity directly influences the fabric handle. Less $B$ value means better fabric handle [22]. Table 6 and figure 6 show bending rigidity $(\mathrm{B})$ and bending hysteresis (2HB) results of sample 01 and sample 02 . Bending hysteresis (2HB) is the ability of the fabric to be recovered. Bending moment required to produce a given curvature which depends upon a number of yarns being bent in fabric and bending rigidity of those yarns. Likewise bending rigidity value, bending hysteresis should be lower results in more fabric elasticity [17]. The values of bending rigidity $(\mathrm{B})$ and bending hysteresis (2HB) are somehow less than polyester/ viscose blended suiting fabric and significantly less than polyester/cotton blended fabric which showed its better fabric handle [18-19].

\section{Compression properties}

Compression properties include 'Linearity of thickness/compression' (LC), compression energy (WC) and compressional resilience (RC) parameters were developed in KES system. This property in Japanese terminology named as FUKURAMI means primary hand feels. Compression energy (WC) defined the bulkiness. Higher values of WC represent higher fabric compressibility [17]. Fabric thickness can affect WC. Compressional resilience ( $R \mathbf{C})$ value appraises the fabric spongy behavior. Actually RC is termed as the ability of fabric to be returned after compressional deformation. Values of all the mentioned parameters are given and shown in table 7 and figure 7 .

Both samples (sample 01 and sample 02) were compared with already measured KES values of some other blends. For this we compared these two samples
Table 7

\begin{tabular}{|l|c|c|}
\hline \multicolumn{1}{|c|}{ Parameter } & Sample 1 & Sample 2 \\
\hline LC [-] & 0.329 & 0.325 \\
\hline WC [g.cm/cm $\left.{ }^{2}\right]$ & 0.161 & 0.198 \\
\hline RC [\%] & 35.78 & 35.15 \\
\hline
\end{tabular}

with polyester/viscose blended suiting fabric, the values of compression property LC (linearity of thickness/compression) and WC (compression energy) of nano-filament fabric are non-significantly greater than PV blended fabric. However; RC (compressional resilience) of $\mathrm{PV}$ fabric and $\mathrm{PC}$ fabric is almost doubled than nano-filament fabric samples [18-19].

\section{Surface properties}

The utmost objective evaluation of comfort in fabrics and materials is carried out by the utilization of surface characteristics. KES system was proposed to narrate the surface properties by the framework of MIU (Coefficient of friction), MMD (Mean Deviation) and SMD (geometrical roughness). Numeri (smoothness) describes this feature in terms of surface property. Study reveals that greater value of confidence of friction characterized in coarse direction rather than wale direction. MMD is also evaluated like MIU. The main cause is the less density of coarse yarns in fabric structure as represented in figure 8 . The MIU value ranges $0-1$ and its approaching value of 1 is interpreted as increasing friction and decreasing smoothness [23]. Frictional coefficient is defined as:

$$
M I U=\frac{F}{P}
$$

Where $F$ is frictional force (in N) and $P$ - sensor load (in N). 


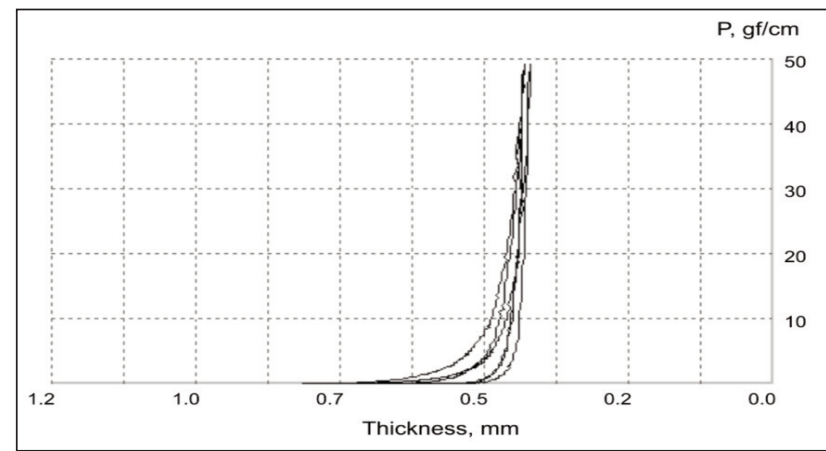

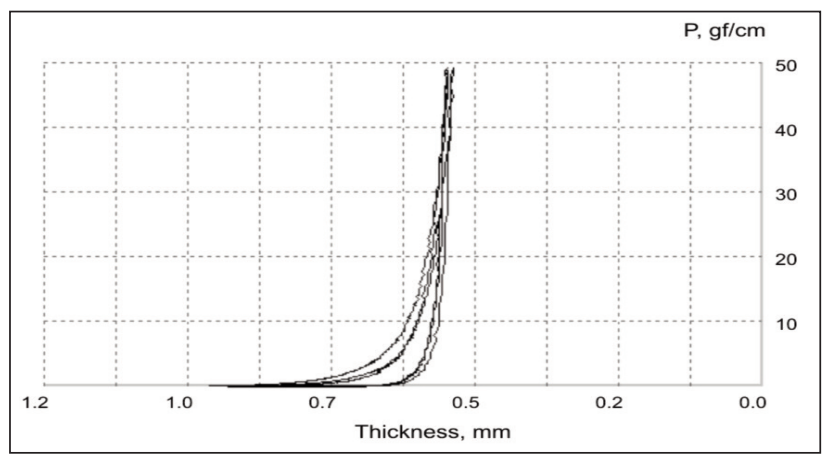

b

Fig. 7. The compression curve for sample 1 and sample 2 in (a) and (b) respectively

Results of geometrical surface roughness (SMD) were carried out to predict the level of significance due to presence of moisture. The SMD values range $0-20$ and as its approaching value of 20 is explained as the increase in the surface roughness and surface irregularities [22]. As comparing with polyester/cotton (50:50) blended fabric the values of MIU (Coefficient of friction), MMD (Mean Deviation) and SMD (geometrical roughness) are $0.154,0.0097$ and 1.60 respectively (table 8). Similarly MIU, MMD and SMD for polyester/viscose fabric showed the $0.195,0.0634$ and 6.83 average value respectively [18-19].

\section{Primary hand values of fabric}

Human response for fabric sensation termed as fabric handle that relates with physical, physiological, perceptional and social factors. These aesthetics property named as appearance and handle are primarily identified by the senses. For the evaluation of fabric as primary hand expressions, used Japanese terms are KOSHI (stiffness), NUMERI (smoothness), and FUKURAMI (softness and fullness). According to Kawabata's hand evaluation and standardization committee, koshi was more important than fukurami in the judgment [23]. High value of THV means lower koshi (stiffness) but higher numeri (smoothness) and fukurami (fullness). High stiffness is problematic for wearer during workout [26].

The resistance to bending, i.e. fabric stiffness, and the fabric weight are major components affecting the method in which a fabric drapes or hangs. The ratio between "fabric resistances to bending" to "weight" is a quantitative estimate of the way the fabric hangs [25]. Bending properties of fabric compared with Koshi. Both nano-filament fabric samples (Sample 01 and sample 02) attribute bending rigidity value is similar to Poly/Viscose blended fabricbut $180 \%$ higher than Poly/Cotton blended fabric [18-19].

Table 8

\begin{tabular}{|l|c|c|c|c|c|c|}
\hline \multirow{2}{*}{ Parameter } & \multicolumn{3}{|c|}{ Sample 1 } & \multicolumn{3}{c|}{ Sample 2 } \\
\cline { 2 - 7 } & Wale & Coarse & Mean & Wale & Coarse & Mean \\
\hline MIU $[-]$ & 0.280 & 0.292 & 0.286 & 0.240 & 0.272 & 0.256 \\
\hline MMD $[-]$ & 0.0108 & 0.0204 & 0.0156 & 0.0107 & 0.0116 & 0.0111 \\
\hline SMD $[\mu \mathrm{m}]$ & 1.25 & 3.43 & 2.34 & 1.46 & 2.54 & 2.00 \\
\hline
\end{tabular}

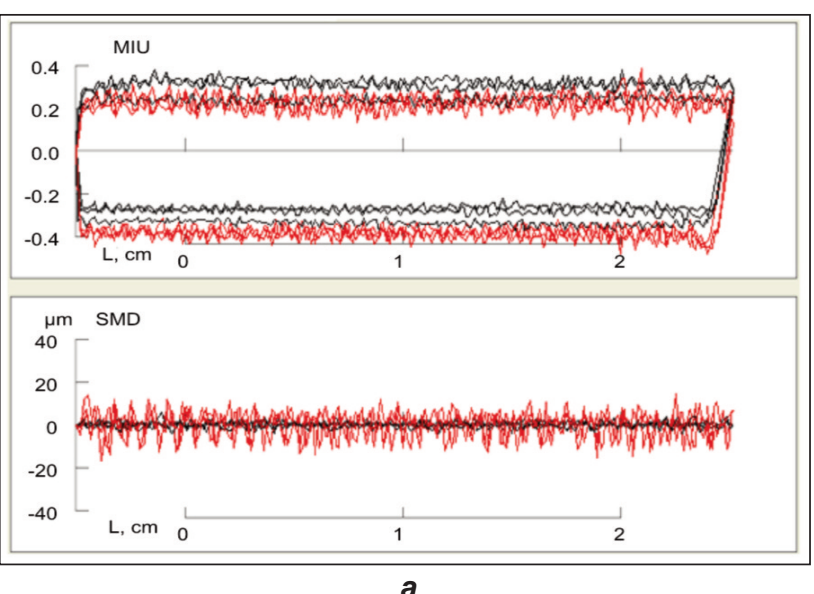

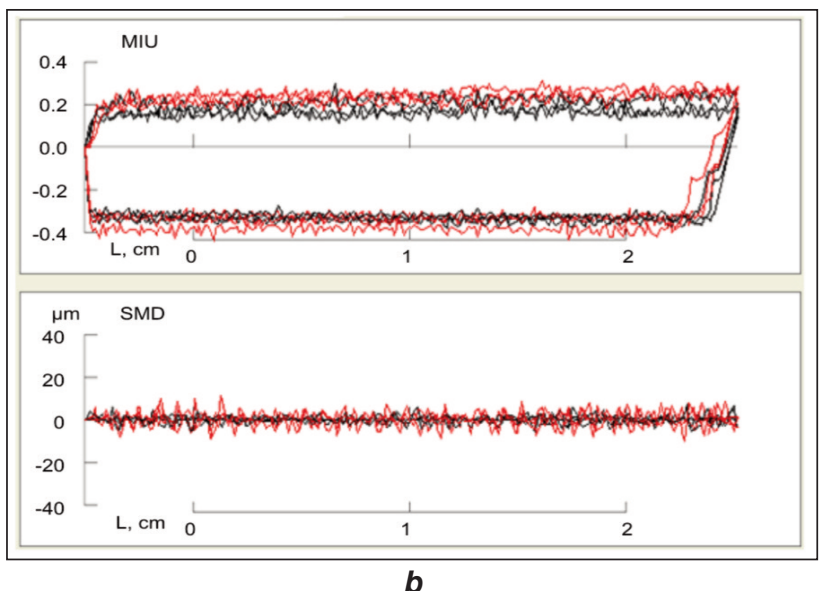

b

Fig. 8. Surface behavior for sample 1 and sample 2. Red curve represents wales direction and black curve courses direction 
Table 9

\begin{tabular}{|l|c|c|c|c|}
\hline Fabric hand value & Sample 1 & Sample 2 & PC & PV \\
\hline Koshi & 3.58 & 2.5 & 6.14 & 4.23 \\
\hline Numeri & 4.21 & 6.91 & 5.71 & 5.77 \\
\hline Fukurami & 4.35 & 6.84 & 4.08 & 4.24 \\
\hline THV & 2.51 & 2.82 & 3.46 & 3.28 \\
\hline
\end{tabular}

As far the basic sensorial comfort is concern, numeri (smoothness) is also a prime factor in the fabric handle characteristics. A fabric that provides little frictional resistance to motion across its surface and owns a low coefficient of friction is presumably called a smooth fabric [25]. Surface property is mainly responsible to describe the Numeri. Sample 1 appeared with less Numeri than sample 02 which may be attributed to the compressional and tensile energies, bending rigidity and hysteresis of shear curve. As comparison with polyester/viscose suiting fabric the Numeri values were high with the increase of polyester content in blend. Likewise the P/C (85:15) blended fabric reported with high Numeri reading [18-19].

Fullness and softness: A springy property in thickness and compression accompanied by a warm feeling is contiguous to this (fukurami means swelling). Fukurami (fullness and softness) is negatively correlated to the summer total hand value [24]. Fullness implicit body and fabric thickness, yields soft surface due to the density of the protruding fibers. Indistinguishable to the Numeri the fullness of sample 2 is higher than sample 1 . This may be imputed to lower compressional resilience and high shear force (table 9). Samples 1 revealed the same results as of polyester/viscoseand polyester/cotton (50:50) blended fabric concerning fullness [18-19].

THV (total hand value) of both samples were considered from primary hand values by KES-system. From the table it was determined that higher values are due to more polyester content in gram per square meter and dense structure. THV of P/C blended fabric and P/V (50:50) blended fabric reported 2.46 almost the same of sample 1 (figure 9).

\section{CONCLUSIONS}

Nano-filament fabrics gave good drapability than normal filament fabric. Nano-filament fabrics also contributed preferable hand values. On average, the total hand values of Nano-filament fabric were equivalent or slightly superior to suiting fabric [18-19]. Nano-filament Polyester fibers have much more absorbent and transport behavior than spun polyester, so the moisture is easily drained from the skin surface and provide the comfort feeling.

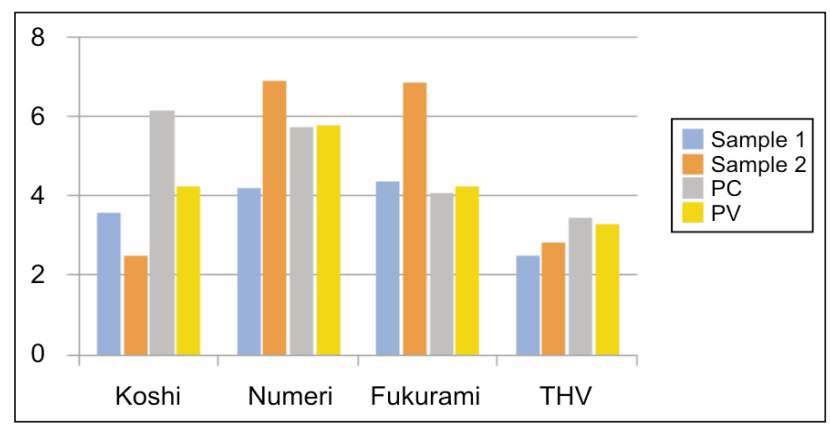

Fig. 9. Total hand value of fabric samples

1. Higher the value of EM and RT better the comfort and fabric handle respectively. Less value of LT gives high elasticity. More WT led to strong tensile but it adversely affect the hand feel. Sample 1 tensile properties were appreciated than sample 2 .

2. The shear rigidly and hysteresis of shear rigidly increased with the gram per square meter of sample 2 as compared to sample 1 . However, less value of shear rigidly is preferable concerning handling.

3. Bending rigidity value defines that how smoothly the fabric is being bent. Less $B$ value means better fabric handle. Both samples graphical represented with same bending rigidity.

4. Compression properties are resemble with FUKURAMI (primary hand feel) of fabric. LC and RC values for both samples are similar due to the same ability of fabric to be returned after compressional deformation.

5. Numeri (smoothness) describes the same feature in terms of surface property. Study reveals that greater value of coefficient of friction (MIU) characterized in lower geometry roughness. MMD is also evaluated like MIU. So sample 1 analyzed as high value of MIU than sample 2 .

6. Koshi was more important than fukurami in the judgment. High value of TVS means lower koshi (stiffness) but higher numeri (smoothness) and fukurami (fullness). High stiffness is problematic for wearer during workout. Sample 1 found good than the sample 2 in this regard.

Industrial point of view: this research is useful for such suiting where comfort and transportation properties are correlated to each other like glove industry. It will also be useful to know about the thickness and GSM requirement for the manufacturer. Nowadays, it is only buyer's market and this study could be deciding factor.

\section{Acknowledgments}

The authors would like to thank the Technical University of Liberec (TUL) for Student Grant (SGS 21200) 2017.

\section{BIBLIOGRAPHY}

[1] Pamuk, O. Clothing comfort properties in textile industry. In: Natural and Applied Sciences, 2008, vol. 3, issue 1.

[2] Mäkinen, M., Meinander, H., Luible, C., Magnenat-Thalmann, N. Influence of physical parameters on fabric hand. Proceedings of the HAPTEX'05 Workshopon Haptic and Tactile Perception of Deformable Objects. Hanover, December, 2005. 
[3] Sajjadi, A., Sheikhzadeh, M., Rikhtehgaran, R., Hajrasouliha, J. Prediction of fabric handle value using ordinal regression model. In: The Journal of the Textile Institute, 2015, vol. 106 issue 1, pp. 1161-1172.

[4] Makinen, M., Meinander, H., Luible, C. Influence of physical parameters on fabric hand. Proceedings of the HAPTEX'05 Workshopon Haptic and Tactile Perception of Deformable Objects (Hanover), 2015, vol. 9.

[5] Unal, P.G., Ureyen, M.E. Mechanical and permeability properties of sportech fabrics.In: Industria Textila, 2016, vol. 67 , no. 3, pp. 151-156.

[6] Yick, K., Cheng, K.P.S., Dhingra, R.C., How, Y.L. Comparison of mechanical properties of shirting materials measured on the kes-f and fast instruments. In: Textile Research Journal, 1996, vol. 66, issue 10, pp. 622-633.

[7] Behera, B.K., Mishra, R.K., Singh, T.G., Sehgal, P. Comfort and handle behaviour of linen and linen blended fabrics. In: Textile Asia, 2007, vol. 38, no. 3.

[8] El Messiry, M., El Ouffy, A., Issa, M. Microcellulose particles for surface modification to enhance moisture management properties of polyester, and polyester/cotton blend fabrics. In: Alexandria Engineering Journal, 2015, vol. 54, issue 2, pp. 127-140.

[9] Sampath, M.B., Mani, S., Nalankilli, G. Effect of filament fineness on comfort characteristics of moisture management finished Polyester knitted fabrics. In: Journal of Industrial Textiles, 2011, vol. 41, issue 2, pp. 160-173.

[10] Yip, J., Ng, S-P. Study of three-dimensional spacer fabrics: physical and mechanical properties. In: Journal of Materials Processing Technology, 2008, vol. 206, issue 1, pp. 359-364.

[11] Park, S.W., Hwang, Y.G. Comparison of Total Hand of Single Knitted Fabrics Made from lincLITE® and Conventional Wool Yarns. In: Textile Research Journal, 2002, vol. 72, issue 10, pp. 924-930.

[12] Chronakis, I.S. Micro-/nano-fibers by electrospinning technology: processing, properties and applications. Micromanufacturing Engineering and Technology. Boston, In: Elsevier, 2010, pp. 264-286.

[13] Wakeham, H., Spicer, N. Pore-size distribution in textiles-a study of windproof and water-resistant cotton fabrics. In: Textile Research Journal, 1949, vol. 19, pp. 705-710.

[14] Harwood, R.J., Weedall, P.J., Carr, C. The use of the Kawabata Evaluation System for product development and quality control. In: Coloration Technology, 1990, vol. 106, issue 2, pp. 64-68.

[15] Kawabata, S. The standardization and analysis of hand evaluation. 2nd edition. In: Textile Machinery Society of Japan (Osaka), 1980.

[16] Kawabata, S., Niwa, M. Objective measurement of fabric mechanical property and quality: Its application to textile and clothing manufacturing. In: International Journal of Clothing Science and Technology, 1991, vol. 3 issue 1, pp. 7-18.

[17] Behera, B.K., Hari, P.K. Woven textile structure: Theory and applications. In: Elsevier, 2010.

[18] Nayak, R.K., Punj, S.K., Chatterjee, K.N. Comfort properties of suiting fabrics. In: Indian Journal of Fibre and Textile Research, 2009, vol. 34, pp. 122-128.

[19] Bartkowiak, G., Frydrych, I., Komisarczyk, A., Greszta, A. Fabric selection for the reference clothing destined for ergonomics test of protective clothing - sensorial comfort point of view. In: AUTEX Research Journal, 2016, vol. 16, issue 4, pp. 256-261.

[20] Hu, J. Structure and Mechanics of Woven Fabrics, In: Elsevier, 2004

[21] Kawabata, S., Niwa, M., Kawai, H. The finite deformation of plain weave fabrics part III, The shear deformation theory. In: The Journal of the textile institute, 1973, vol. 64, issue 1, pp. 62-85.

[22] Yazdi, A., Shahbazi, Z. Evaluation of the bending properties of viscose/polyester woven fabrics. In: Fibres \& Textiles in Eastern Europe, 2006, vol. 14, pp. 50-54.

[23] Nawaz, N., Troynikov, O., Watsonc, C. Evaluation of surface characteristics of fabrics suitable for skin layer of firefighters' protective clothing. In: Physics Procedia, 2011, vol. 22, pp. 478-486.

[24] Sun, M.N. A new tester and method for measuring fabric stiffness and drape. In: Textile Research Journal, 2008, vol. 78 , issue 9 , pp. 761-770.

[25] Mondal, S., Reddy, V., Sarkar, A., Aravindakshan, P., Ghatak, A. Effect of surface modification on frictional properties of polyester fabric. In: Tribology International, 2016, vol. 97, pp. 38-48.

[26] Ajayi, J.O. Fabric smoothness, friction, and handle. In: Textile Research Journal, 1992, vol. 62, issue 1, pp. 52-59.

\section{Authors:}

\section{MUSADDAQ AZEEM MSc. ${ }^{1}$}

Eng. AMAL BOUGHATTAS ${ }^{2}$

Eng. HAFIZ FAISAL SIDDIQUE MSc. ${ }^{1}$

doc. Eng. ANTONIN HAVELKA CSc. ${ }^{1}$

Eng. SAJID HUSSAIN MSc. ${ }^{1}$

${ }^{1}$ Technical University of Liberec, Faculty of Textile Engineering

Studentska 1402/2, 461 17, Liberec 1, Czech Republic.

${ }^{2}$ Monastir University, National School of Engineers, Department of Textile Engineering

Avenue Ibn Eljazzar-5019 Monastir-TUNISIA

Corresponding author:

\section{MUSADDAQ AZEEM}

e-mail: musaddaq.azeem@tul.cz 